University of South Carolina

Scholar Commons

$12-2008$

\title{
Music Librarian as Development Officer: Raising Funds for Special Collections
}

Ashlie K. Conway

University of South Carolina - Columbia, conwaya@mailbox.sc.edu

Follow this and additional works at: https://scholarcommons.sc.edu/lib_facpub

Part of the Library and Information Science Commons, and the Music Commons

\section{Publication Info}

Preprint version Music Reference Services Quarterly, Volume 11, Issue 3-4, 2008, pages 203-228.

http://www.tandf.co.uk/journals/WMUS

(c) 2008 by Taylor \& Francis

This Article is brought to you by the University Libraries at Scholar Commons. It has been accepted for inclusion in Faculty and Staff Publications by an authorized administrator of Scholar Commons. For more information, please contact digres@mailbox.sc.edu. 


\section{The Music Librarian as Archivist and Development Officer: Raising Funds for Special Collections}




\section{Contents}

Introduction $\quad 3$

Literature Review

$\begin{array}{ll}\text { Strategies for Fundraising } & 13\end{array}$

Conclusions and Further Recommendations 16

$\begin{array}{ll}\text { Appendix A } & 17\end{array}$

$\begin{array}{ll}\text { Appendix B } & 18\end{array}$

$\begin{array}{ll}\text { Appendix C } & 20\end{array}$

$\begin{array}{ll}\text { Bibliography } & 22\end{array}$ 


\section{INTRODUCTION}

According to Clark, ${ }^{1}$ the first attempt to raise funds for higher education occurred in 1641 when "Harvard College dispatched three preachers to England on a fund raising expedition." Since then, libraries as a whole have developed and evolved to match current computer-driven technology. Today, libraries have endless possibilities to digitize and preserve materials. Chief among these possibilities are special collections. Special collections web pages in music libraries can display the scanned manuscript score, photographs, or even streaming movie or audio files containing interviews of a composer; these digital surrogates protect the original materials.

The unique sizes and mediums of music materials found in music special collections can pose a difficult and very expensive challenge when purchasing archival materials, audio or visual playback and editing equipment. Music librarians in charge of special collections sometimes find themselves shopping around for the best deals on archival materials. However, "special collections libraries have long provided leverage for larger institutional fundraising efforts by providing exhibitions, private viewings..."2 and other special events. If special collections are a money maker for the institution, who or what is making the money to preserve and digitize the special collections?

Even more unfortunate is the attitudes often held by librarians about fundraising. Little specific literature exists on fundraising, and even less training is offered. "Prior development experience" was listed in over three-fourths of job listings within a six

\footnotetext{
${ }^{1}$ Charlene Clark, "Getting Started with Annual Funds in Libraries." Journal of Library Administration 12, no. 4. (1990): 73.

${ }^{2}$ Lisa Browar and Samuel A. Streit, "Mutually Assured Survival: Library Fund-raising Strategies in a Changing Economy," Library Trends 52, no. 1 (Summer 2003): 70.
} 
month period on the Chronicle of Higher Education. ${ }^{3}$ Almost all library fundraising literature points back to Eaton's 1971 study, in which was found that librarians often feel that fundraising is "a responsibility which primarily belongs to others."

So if the librarians don't feel responsible or knowledgeable enough to raise funds, and as is often the case in music libraries, they don't have access to a development officer, who (and how) will money be raised? To get a further insight, a brief, informal survey was sent to random music institutions with special collections or archives (either print or sound). See Appendix A for the survey.

Initially, the survey was sent to all the members of the listserv for the Southeast chapter of the Music Library Asssociation, or SEMLA. After several weeks with no response, the same survey was sent to all Music Library Association (MLA) chapters with listserv information available. Additionally, the terms "music library special collection" were entered into a Google search. Each returned website was checked for accuracy of results, and email addresses were gathered for directors, heads, music librarians, archivists, or special collections directors from said sites. The survey was also sent to these addresses. At the time of writing, only two responses had been collected. The unedited responses are in Appendix B.

\footnotetext{
${ }^{3}$ Mark D. Winston and Lisa Dunkley, "Leadership Competencies for Academic Librarians: The Importance of Development and Fund-Raising," College \& Research Libraries News 63, no. 2 (March 2002): 6 .

${ }^{4}$ Victoria Steele and Stephen D. Elder, Becoming a Fundraiser: The Principles and Practice of Library Development (Chicago: American Library Association, 1992) ix.
} 


\section{LITERATURE REVIEW}

There is no literature on fundraising for special collections in music libraries. In fact, there is very little literature for fundraising in music libraries as a whole. The sources used in this literature review primarily are made up of general library fundraising sources, academic library sources, and archives funding sources. Generalizations will be made so that the information can be applied to special collections in music libraries.

There are very few dissertations or theses in library fundraising. Most are the end products of extensive surveys, either in a very narrowed, specific area of fundraising, or a very broad, generalized, nation-wide search for information. Gene Crutsinger's Master's research paper on fundraising in Seminary Libraries represents the specific end of the spectrum. Crutsinger's research names eight specific projects and improvements to be undertaken at the Winebrenner Theological Seminary Library, only one of which is applying for grants. The other suggestions offered by Crutsinger are public relations or intra-University related. ${ }^{5}$

Terry Latour takes an opposite approach in his library fundraising research. Latour developed extensive and highly detailed surveys which were mailed to Library Directors of Universities picked from a random sampling of Carnegie Classification institutions. Some of his research questions were:

1) To what extent do academic libraries initiate and engage in extra-institutional fund raising activities?

2) Are there significant statistical relationships between the types of fund raising programs engaged in, the sizes and types of institutions, the amount of staff

\footnotetext{
${ }^{5}$ Gene Crutsinger, "Introducing Fundraising to a Seminary Library" (master's thesis, Kent State University, 1999), 30-8.
} 
time and resources devoted to the effort, and success rates of the programs? ${ }^{6}$

Latour found that "approximately two-thirds of all academic libraries" in his sample fundraise. ${ }^{7}$ Most fundraise to bridge the gap between their current budgets and increasing materials and equipment costs. These libraries are successful around $70 \%$ of the time, but success depends on geographic area and type of institution. ${ }^{8}$

The selection of books on this topic is just as varied as the research documents. The bulk of the books published deal with public library fundraising. As public libraries differ greatly from academic institutions, these books were disregarded. Books on fundraising in academic libraries, archives or special collections were reviewed. The Music Library Association is currently working on a book of music library fundraising, but this book will not be available until late 2008 .

Within the available texts, several format themes appeared. First, some of the books are a survey of different types of fundraising approaches. Among these are James Swan's Fundraising for Libraries: 25 Proven Ways to Get More Money for Your Library, ${ }^{9}$ Lee and Hunt's Fundraising for the 1990s The Challenge Ahead: A Practical Guide for Library Fundraising; From Novice to Expert, ${ }^{10}$ Victoria Steele and Stephen Elder's Becoming a Fundraiser: The Principles and Practice of Library Development ${ }^{11}$ and a few others. These books feature chapters ranging from the basics of fundraising to development, public relations, physical building funds, retail shops, Friends groups,

\footnotetext{
${ }^{6}$ Terry Stephen Latour, "Study of Library Fund Raising Activities at Colleges and Universities in the United States" (PhD diss., Florida State University, 1995), 14.

${ }^{7}$ Ibid., 231-2.

${ }^{8}$ Ibid., 232-4.

${ }^{9}$ James Swan, Fundraising for Libraries: 25 Proven Ways to Get More Money for Your Library (New York: Neal-Schuman Publishers, 2002).

${ }^{10}$ Hwa-Wei Lee and Gary A. Hunt, Fundraising for the 1990s The Challenge Ahead: A Practical Guide for Library Fundraising; From Novice to Expert (Canfield, OH: Genaway \& Associates, 1992).

${ }^{11}$ Steele and Elder, Becoming a Fundraiser.
} 
grants, and black-tie, or other special events. While giving a great beginner's overview, these books often lack specifics. Generalizations can be made from these books for music libraries as a whole, but are often rarely applicable to special collections, much less music special collections fundraising.

Second, case studies of actual fundraising projects undertaken by academic libraries are commonly found resources. Meredith Butler's Successful Fundraising: Case Studies of Academic Libraries ${ }^{12}$ and SPEC Kits $193^{13}$ and $297^{14}$ from the Association of Research Libraries (ARL) are highly specific facsimiles of documents used by institutions in (successful) pursuit of funding. To the novice fundraiser, these documents can be intimidating and bewildering. These resources should not be used at the start of one's fundraising research. The documents will not make much sense until some basic terms and processes are understood. However, once the researcher feels comfortable studying processes and examples of prior fundraising attempts, these resources become invaluable. The SPEC Kits give the to-be-fundraiser an insight to formats, correspondence, public relations, surveys, and other information easily adaptable to music special collection fundraising, or any other institutional fundraising.

Third, a handful of resources on a specific fundraising topic or sub-topic were available. Included here are Corson-Finnerty and Blanchard's Fundraising and FriendRaising on the Web, ${ }^{15}$ Sally Gardner Reed's Making the Case for Your Library: A How-

\footnotetext{
${ }^{12}$ Meredith Butler, ed., Successful Fundraising: Case Studies of Academic Libraries (Washington, DC: Association of Research Libraries, 2001).

${ }^{13}$ Lynda C. Claassen, comp., Library Development and Fundraising: A SPEC Kit, ed. Brigid Welch (Washington, DC: Association of Research Libraries, 1993).

${ }^{14}$ Karlene Noel Jennings and Jos Wanschers, eds, SPEC Kit 297: Library Development (Washington, DC: Association of Research Libraries, 2006).

${ }_{15}$ Adam Corson-Finnerty and Laura Blanchard, Fundraising and Friend-Raising on the Web (Chicago: American Library Association, 1998).
} 
To-Do-It Manual, ${ }^{16}$ and Grabowski's chapter in American Archival Studies: Readings in Theory and Practice. ${ }^{17}$ These resources vary greatly. Fundraising and Friend-Raising on the Web deals strictly with fundraising via library websites and includes a CD-ROM. Although the source is outdated by today's technology standards (it was published in 1998), some of the information is applicable and viable for music library websites, and especially the special collections pages within said websites. "Keepers, Users and Funders" and Making the Case for Your Library are more public relations tools than direct fundraising resources. However, many experienced fundraisers and development officers will agree that libraries and librarians need to "communicate not just what their library is doing, but why it matters.... When you focus on 'why it matters,' you expand your public relations reach beyond potential users to potential supporters...." ${ }^{18}$ Reed elaborates by stating that:

This book will show you how to use traditional promotional materials and techniques to make your library and its services matter to everyone in your community, public or academic, whether they use your library or not. If you garner more users in the process, you will have expanded your support base and will have made your library more directly meaningful to more people. ${ }^{19}$

Also available are chapters on fundraising within library, preservation or other resources. These include Nancy Gwinn's report in To Preserve and Protect: The Strategic Stewardship of Cultural Resources and Judy Hohmann's “Money Talk”

\footnotetext{
${ }^{16}$ Sally G. Reed, Making the Case for Your Library: A How-To-Do-It Manual (New York: NealSchuman, 2001).

${ }^{17}$ John J. Grabowski, "Keepers, Users, and Funders: Building an Awareness of Archival Value," in American Archival Studies: Readings in Theory and Practice, ed. Randall C. Jimerson, (Chicago: The Society of American Archivists, 2005), 619-29.

${ }^{18}$ Reed, Making the Case for Your Library, xiii.

${ }^{19}$ Reed, Making the Case for Your Library, xv.
} 
chapter in Advocating Archives: An Introduction to Public Relations for Archivists. ${ }^{20}$

These chapters are often include good information, but are not directed at the fundraising-only audience. While both of the books are specifically directed at those who care for archives and special collections, the information included is generally a broad overview or sometimes a case study of a selected library's efforts.

There are an overwhelming amount of journal articles on fundraising. Searching for fundraising articles can be difficult at best. Some authors and databases use the term "fund raising" instead of "fundraising," while some only use the term "development." Once the articles are located, one will see how diverse and extremely varied the content can be.

In the winter of 2000, Library Trends devoted an entire issue to fundraising. The articles within covered a wide range of topics including public relations, ${ }^{21}$ organization and process of beginning fundraising efforts, ${ }^{22}$ annual funds, ${ }^{23}$ online fundraising, ${ }^{24}$ surveys, ${ }^{25}$ and other topics. These articles range in complexity from novice-level information to rather complex, advanced level facts and figures. Overall, this journal issue includes the best "all-around" information for all levels of fundraisers, and should not be overlooked.

Within the journals, there are a few recurring themes: technology, digitization,

${ }^{20}$ Judy P. Hohmann, "Money Talk," in Advocating Archives: An Introduction to Public Relations for Archivists, ed. Elsie Freeman Finch, (Metuchen, NJ: The Society of American Archivists and the Scarecrow Press, 1994), 23-38.

${ }^{21}$ Robert Wedgeworth, "Donor Relations as Public Relations: Toward a Philosophy of FundRaising," Library Trends 48, no. 3 (Winter 2000).

${ }^{22}$ Susan K. Martin, "Academic Library Fund-Raising: Organization, Process and Politics," Library Trends 48, no. 3 (Winter 2000).

${ }^{23}$ Jennifer Paustenbaugh and Lynn Trojahn, "Annual Fund Programs for Academic Libraries." Library Trends 48, no. 3 (Winter 2000).

${ }^{24}$ Adam Corson-Finnerty, "Cybergifts,” Library Trends 48, no. 3 (Winter 2000). 
and websites; traditional fundraising overviews; fundraising for preservation; and other tips. Technology, digitization and websites is a very lose categorization that includes Brenda Hazard's survey of fundraising on ARL websites, ${ }^{26}$ Nancy Gwinn's article on funding for digitization projects, ${ }^{27}$ Stephanie Gerding and Pam Mackellar's article on technology grants, ${ }^{28}$ and Jeanie Welch's article on marketing and public relations via the academic library website. ${ }^{29}$ All of these articles discuss using the most up-to-date technologies to assist the library in getting funds.

Traditional fundraising overviews include Martin’s academic library director article, ${ }^{30}$ McCune's tips, ${ }^{31}$ and Alexander's small shop advantage. ${ }^{32}$ As expected, these articles include information on traditional funding routes: using a development officer, writing grants, annual funds, partnerships with other institutions, Friends groups, and gifts. Also included is good information on the use of library staff, donor relations and organization to begin the fundraising process.

Fundraising for preservation includes only two articles: Paustenbaugh's ${ }^{33}$ short

${ }^{25}$ Irene M. Hoffman, Amy Smith and Leslie DiBona, "Factors for Success: Academic Library Development Survey Results," Library Trends 48, no. 3 (Winter 2000).

${ }^{26}$ Brenda L. Hazard, "Online Fundraising at ARL Libraries," Journal of Academic Librarianship 29, no.1 (January 2003).

${ }^{27}$ Nancy Gwinn, "Mapping the Intersection of Selection and Funding." Collection Management 22, no. 3/4 (1998).

${ }^{28}$ Stephanie Gerding and Pam Mackellar, "Wishing Won't Work: 10 Things you Need to KNOW and DO When Applying for Technology Grants," Computers in Libraries 26, no. 7 (July/August 2006).

${ }^{29}$ Jeanie M. Welch, "The Electronic Welcome Mat: The Academic Library Web Site as a Marketing and Public Relations Tool." The Journal of Academic Librarianship 31, no. 3 (May 2005).

${ }^{30}$ Susan K. Martin,"The Changing Role of the Library Director: Fund-raising and the Academic Library," Journal of Academic Librarianship 24, no. 1 (January 1998).

${ }^{31}$ Bonnie McCune, "10 Tips for Getting Grants to Keep Your Library Afloat," Computers in Libraries 27, no. 7 (July/August 2007).

${ }^{32}$ Johanna O. Alexander, "Fundraising for the Evolving Academic Library: The Strategic Small Shop Advantage," The Journal of Academic Librarianship 24, no. 2 (1998).

${ }^{33}$ Jennifer Paustenbaugh, "Fundraising for Special Collections." The Bottom Line: Managing Library Finances 15, no. 4 (December 2002). 
overview, and Shoaf's ${ }^{34}$ even shorter case study. Paustenbaugh generally writes on special collections funding, while Shoaf considers traditional preservation tactics along with digitization "for future use of preservation technologies not yet fully developed." 35 Though seemingly on the same topic, Paustenbaugh's article deals with funding via donations and donors, and Shoaf's article deals with grants instead. Paustenbaugh stresses all forms of communication as key to gaining and keeping donors, along with building “a history of ... excellent care to [the library's] collections and professional stewardship....This includes following best practices for processing, preserving and making accessible existing collections and knowing how much these activities cost."36 Conversely, Shoaf alludes to somewhat disguising information: Brown University wrote a grant proposal based heavily on traditional preservation methods, but with the additional digitization to the occasional item. Disguising (although Shoaf never directly says this was his intention) the digitization aspect made Brown University more likely to get the grant they had applied for.

There are a few articles that offer other fundraising suggestions outside grants, development, annual funds, Friends groups, and other traditional ways. Janet L. Balas's $\operatorname{article}^{37}$ is a good primer in web-based resources for funding. Balas's list of 12 webbased resources on library fundraising are discussed in detail. While mostly geared toward public libraries, a few of the resources can be helpful for music librarians in charge of fundraising. Especially applicable to music librarians fundraising for special

${ }^{34}$ Eric C. Shoaf, "Brown University Library Meets the Preservation Challenge: A Challenge Grant Leads to a Preservation Endowment," College \& Research Libraries News 61, no. 7 (August 2000).

35 Ibid., 2.

${ }^{36}$ Paustenbaugh, "Fundraising for Special Collections," 1. (2006).

${ }^{37}$ Janet L. Balas, "Looking for Funds in All the Right Places," Computers in Libraries 26, no. 8 
collections are the TechSoup website and the American Library Association (ALA) resources listed.

Another article with different options for fundraising is by Andrew Pace. ${ }^{38}$ Pace's article is markedly different than any others reviewed. Pace starts off by saying that he is not interested in writing grants, nor is he interested in "any kind of fundraising, period." 39 Pace then goes on to suggest that instead of grant writing or fundraising, librarians should: have higher pay for systems or information technologists (IT) negotiate with vendors until "it hurts," and finally, charge patrons for printing, librarian-led research, and rental fees for audio or visual materials. While negotiations with vendors do not effect special collections, IT salaries and charging patrons can possibly effect the use and/or finances of special collections if implemented.

Finally, the title of Winston and Dunkley's article ("Leadership Competencies for Academic Librarians: The Importance of Development and Fund-raising") ${ }^{40}$ may be a bit misleading, but the article is certainly worth reviewing. This article isn't so much about character traits of librarians as it is a hefty review of literature and survey of job titles as posted on The Chronicle of Higher Education. The literature review addresses some key foundations for the purpose of this paper and recommendations for the future:

Of the extensive body of literature on development and fund-raising in academic libraries, the research literature does not address the knowledge and the skill set that librarians need to be effective fundraisers for their organizations....It appears that the educational preparation offered in most graduate library and information science (LIS) programs does not address issues of development and fund-raising to a large extent. ${ }^{41}$

${ }^{38}$ Andrew K. Pace, "Money Makes the Library Go 'Round." Computers in Libraries 23, no. 2 (February 2003).

${ }^{39}$ Ibid., 2.

${ }^{40}$ Mark D. Winston and Lisa Dunkley, "Leadership Competencies for Academic Librarians: The Importance of Development and Fund-Raising," College \& Research Libraries News 63, no. 2 (March 2002).

${ }^{41}$ Ibid., 2. 


\section{STRATEGIES FOR FUNDRAISING}

Although the authors of the selected resources approached their writings about fundraising in different manners, many had the same observations. Throughout all the reviewed fundraising literature, four major themes appeared: writing grants, development officers and tactics, annual funds and Friends groups, and other strategies.

\section{$\underline{\text { Grants }}$}

All sources reviewed agree on two basic things to prepare grant writers-to-be:

planning and team building. For music librarians in charge of special collections, planning should consist of two parts: a preservation plan, and a technology plan. A preservation plan is derived from the institution's mission statement, policies, and priorities, includes:

A statement of need that describes and qualifies the preservation challenge, definitions of preservation concepts and terms, discussion of institutional preservation priorities, strategies for selection for preservation, an outline of the preservation program..., and a discussion of consortial and cooperative relationships and opportunities with other libraries. ${ }^{42}$ Included within the parts of the preservation plan are: goals of the preservation program, the activities necessary to reach the goals, designated responsibility for each activity, resources required to carry out the activity, and a time schedule of each activity. ${ }^{43}$

If the preservation plan does not include technology, then a separate technology plan must be made. The technology plan will follow the same outline, but is "a method to prioritize and to budget for the technology tools that are most important for achieving the

\footnotetext{
${ }^{42}$ Carolyn Clark Morrow, "Defining the Library Preservation Program: Policies and Organization," in Preservation: Issues and Planning, ed. Paul N. Banks and Roberta Pilette (Chicago: American Library Association, 2000), 6.

${ }^{43}$ Christine Ward, "Preservation Program Planning for Archives and Historical Records Repositories," in Preservation: Issues and Planning, ed. Paul N. Banks and Roberta Pilette (Chicago: American Library Association, 2000), 52.
} 
library’s goals." ${ }^{44}$ When requesting funds for computers, a technology plan is often required to be sent in along with the grant paperwork. ${ }^{45}$

Once the plans have been developed, a team must be built. Some sources state that members of the community, selected library staff, and business people should be involved; other sources state that the library's development office along with the head librarian and special collections director (if not the same as the head librarian) should compose the team. Either way, once the team is put together, the next step is to develop a project.

Putting together the project requires looking "carefully at the goals, objectives, and activities in all parts of your library...."46 Once potential projects have been identified, outcomes, goals, objectives, steps and a timeline must be clarified. During this period, research must be completed through case studies and similar projects. According to Dewey:

It is often more effective...to read examples of successful grant applications. Funded grant applications are public documents and should be available from the funding agency or the institutions receiving the award. Studying funded proposals reveals not only how a successful application is constructed, but also confirms the type of projects the agency chooses to fund. ${ }^{47}$

These documents are available, along with numerous case studies and SPEC Kits, all which provide facsimiles of actual grant documents.

Once the details of the project have been agreed upon, finding a grant to apply for is the next step. Grants come from either government sources, or private sources. A few granting sources that are key for humanities with special collections to know about are

\footnotetext{
${ }^{44}$ Gerding and Mackellar, "Wishing Won't Work," 3.

${ }^{45}$ Ibid.

${ }^{46}$ Ibid.
} 
grants.gov; Institute of Museum and Library Services (IMLS); the National Endowment for the Humanities (NEH); the Association of Recorded Sound Collections (ARSC); local civic groups; local businesses; and the Grammy Grant Foundation. ${ }^{48}$

\section{$\underline{\text { Writing Your Grant }}$}

Every grant has different guidelines and requirements for application. However, a few components of grant applications are frequently seen. These include a cover sheet with summary, objectives and justification, institutional information, methodology (including personnel and plan for implementation), budget, outcome reports, and sometimes publicity. ${ }^{49}$

Regardless of the grant applied for, all documents should be clear, concise and realistic. Merrily E. Taylor wrote about grant writing briefly in Successful Fundraising:

Case Studies of Academic Libraries. Taylor stated that:

A [grant] proposal should describe a project or program that can actually be implemented. It must be realistic in terms of projected resources, timelines, staff capacities and outcomes.... The best proposals will speak to the heart of a funding agency's mission and excite agency staff, as well as the panelists who serve as readers for the program. ${ }^{50}$

\section{Development}

Steele and Elder defined development as the following:

Library development is a carefully orchestrated, purposive effort to raise substantial sums of money by identifying and cultivating potential donors and by soliciting gifts from them when their goals and wishes are congruent with the

${ }^{47}$ Barbara I. Dewey, ed. Raising Money for Academic and Research Libraries: A How-To-Do-It Manual for Librarians. (New York: Neal-Schuman Publishers, 1991): 59.

${ }^{48}$ Gerding and Mackellar, "Wishing Won't Work," 5-6.

${ }^{49}$ Dewey, Raising Money for Academic and Research Libraries, 60-64.

${ }^{50}$ Butler, Successful Fundraising, 40-41. 
library's goals and priorities. ${ }^{51}$

There is a widespread debate within the library community about who should do the fundraising. Some sources state that fundraising should only be done by development professionals. These professionals should have the right temperament and training, and their sole focus is finding and courting resources for your library. However, most music libraries do not have their own development officer. Often the main library will have an available development officer; the downfall here is that they are not familiar with the special needs of the music library and its special collections.

The other side of the debate says that "money wants to talk to power." 52 This side of the debate says that major donors do not want to talk to a lower-level staff member, or any development officer. Donors want to work with library directors to ensure their gift will become a success.

A 1993 study showed that a total of $\$ 126$ billion was raised in private contributions to non-profit institutions. Of this $\$ 126$ billion, $87 \%$ came from individuals, $7.3 \%$ came from private foundations, and $4.7 \%$ came from corporations. ${ }^{53}$ All sources state that development is difficult to learn and master, and requires a long-term commitment. Key to mastering development is a basic understanding of people. Hood cites Harold Seymour's "Design for Fundraising" and his three underlying principles:

1) To be asked to participate (people want to be sought)

2) To feel he or she is a member of a worthwhile group (people want to belong)

3) To be responsible for continuity (people want to be remembered)

The key to unlocking this third aspect is putting the "emphasis on the needs that exist in

\footnotetext{
${ }^{51}$ Steele and Elder, Becoming a Fundraiser, 22-23.

52 Steele and Elder, Becoming a Fundraiser, 15.

${ }^{53}$ Clark, "Getting Started with Annual Funds in Libraries," 73.
} 
the society, not the emphasis on the organization's needs." 54 This emphasis is preservation of special collections materials already held by your music library, and digitization of the same materials so that patrons (both physical and virtual) can make use of the materials.

Once you understand the basic needs of people, you can apply these to your development tactics. "The four key words in fundraising: identification, cultivation, solicitation, and stewardship." ${ }^{, 55}$ Identification is simply that: identifying potential sources of income for your library. Cultivation is a multi-part task that involves inviting the potential donor into your library, educating the potential donor about your library, and getting the donors involved in your library. This can be done with a library visit or even a visit to the library's website. This is when you show the potential donor that you are seeking out help; you are asking them to participate in your organization. Once they have agreed to participate, you may move on to solicitation. Solicitation involves asking the donor for a gift, but only after enough time and participation has occurred with you and your library. Stewardship is the continuing relationship between you and your donor. This includes communication on how the gift is being used, and possible communications about additional gifts at a later date. ${ }^{56}$

According to Hood, there are three ways of asking for donations. First is by a "written appeal" to the potential donor. Second is through phone communications, and third is by personal visits. The larger the potential gift, the more one-on-one time should

54 Ibid.

55 Joan M. Hood, "Financing Library Services: Changing Approaches - Finding New Sources of Financial Aid for Libraries." Conference Proceedings of the Sixty-Second IFLA General Conference. (August 1996), http://www.ifla.org/IV/ifla62/62-hooj.htm

56 Ibid. 
be required. ${ }^{57}$

\section{Annual Funds via Friends Groups}

Annual funds differ from major giving in a few key ways. First, there is a division of labor between major gifts prospecting and organizing annual funds through a Friends group. There is also a division of time invested, and the amount of the gift to be received. ${ }^{58}$

Clark states that "the bread and butter of fundraising in higher education today is the annual fund.... ${ }^{, 59}$ These annual funds are commonly developed by Friends groups. "Many academic Friends groups were established specifically to assist in raising support for manuscript and rare book collection typically in the humanities... ${ }^{60}$ Friends groups encourage donations to libraries by creating a social network for the donors. ${ }^{61}$ Friends groups typically have regular meetings and create a purpose statement. Unfortunately, there is often an unclear nature found in many Friends groups purpose statements. Clark reviewed the purpose statements of many different library friends groups. She found that most groups have a primarily social nature, and do not mention, or indirectly mention fundraising. This unclear purpose statement can be traced back to the friends and librarian's mutual ambivalence, uneasiness, or fear of disappointment about their fundraising efforts. ${ }^{62}$ Clark also reviewed a work by Michael Haeuser, who details the necessary criteria for successful friends groups.

${ }^{57}$ Ibid.

${ }^{58}$ Steele and Elder, Becoming a Fundraiser, 25-26.

${ }^{59}$ Clark, "Getting Started with Annual Funds in Libraries," 74.

${ }^{60}$ Ibid., 76.

${ }^{61}$ Winning the Money Game: A Guide to Community-Based Library Fundraising (New York: The Baker \& Taylor Company, 1979):64.

${ }^{62}$ Clark, "Getting Started with Annual Funds in Libraries," 76-77. 
The Friends group should be a fairly autonomous group with strong and highly visible leadership from volunteers who possess fund raising experience. Leaders should also be enthusiastic, visionary, and well-connected. Library staff...should not dominate the group....Although the primary purpose of the group may be fund raising, a social component... is indispensable. ${ }^{63}$

So how exactly does a Friends group equal annual funds for your library? Two ways: membership and events. ${ }^{64}$ Membership fees to join the friends group are the basis of annual funds. Leadership donors and major gift prospects are likely to come from [a friends of the library] group." ${ }^{, 65}$ The rule of thirds helps you develop an estimated gift table from the membership of your Friends group. To further explain, Clark cites Jerold Panas: "One third of your money comes from about your top ten donors, and the next third from about the following one hundred donors. ${ }^{, 66}$ With a broad base of low-level memberships, a large amount of money can be raised in a small amount of time.

The second half of annual funds created by Friends groups comes from special events. These types of events can range from $5 \mathrm{k}$ run-walk events; to book, art, or record appraisal clinics; to book or bake sales; to high-end picnics; to surf-a-thons (where members are sponsored to see how long they can consecutively "surf" the internet) or other "-a-thon" activities. These activities reinforce the fun aspect of helping the library. "While contributing of themselves, [participants] become more aware of the library's services and what it means to the community....An event that generates positive publicity for the library can also serve to make friends among those whose interest and support previously seemed elusive.. ${ }^{, 67}$ Special events held once yearly are usually successful in raising a moderate amount of money (depending on the size of the Friends

\footnotetext{
${ }^{63}$ Ibid.

${ }^{64}$ Ibid., 78 and 81.

${ }^{65}$ Clark, "Getting Started with Annual Funds in Libraries," 74.

${ }^{66}$ Ibid., 83.
} 
group and amount of time invested in preparing the event). ${ }^{68}$ Keep in mind that the size of your Friends group isn't as important as its age. Well-established groups (of ten years or more) donate more than groups with large memberships. ${ }^{69}$

\section{$\underline{\text { Other Sources }}$}

One major type of fundraising outside of the above methods is planned giving. This includes bequests (also known as deferred giving), gifts-in-kind, and many more sophisticated options. Pamela Bonnell defined deferred giving as: "a mechanism that allows a donor to bequeath money or stock [sometimes even property] according to his or her will upon death. Because of tax laws, it is highly recommended that an attorney and financial planner be involved.,70

Gifts-in-kind make up the majority of charitable giving, and can be the backbone of support for a burgeoning music special collection. Gifts-in-kind are items given to the library, and can range from manuscripts, recordings, entire collections, photographs, notebooks, and many other item types. ${ }^{71}$

There are endless possibilities for non-traditional funding sources. Not all of these are appropriate or fully applicable for special collections fundraising. A few of these are bake sales, memorial gifts, special events, and gift shops. The librarian or special collections director must decide what is appropriate and feasible for his or her library and collections.

67 Winning the Money Game, 39-40.

${ }^{68}$ Clark, "Getting Started with Annual Funds in Libraries," 81-82.

${ }^{69}$ Ibid., 77.

${ }^{70}$ Pamela G. Bonnell, Fund Raising for the Small Library (Chicago: American Library Association, 1983): 4.

${ }^{71}$ Dewey, Raising Money for Academic and Research Libraries, 94-95. 


\section{CONCLUSIONS AND FURTHER RECOMMENDATIONS}

The International Council on Archives met in Haarlem, Netherlands in 1991 to produce recommendations on how to finance archival services. Of these recommendations, a few were key:

1) Archives of a public nature should be financed principally by public funds, and at no time should it require private funding for its core operations.

2) Development of new products and services will enhance the status of the archive and bring in additional resources and funding.

3) "Archivists must develop expertise in financial management..." and should improve and monitor their cost-effectiveness.

4) Fundraising for archives is an "urgent necessity" and archives should "develop a definite policy" and guidelines on fundraising. Research on fundraising is also integral. ${ }^{72}$

There is no question that more research must be done on the fundraising habits of music libraries, including detailed surveys on the types and formats of special collections held, and types of funding pursued. Included in these surveys should be information about the library staff, especially as to whether or not partnerships occur between the head librarian, special collections director, and university development officer (if available). More literature must become available, as more music libraries and developing their own special collections. Music libraries with special collections have the highest need to preserve, but will also have some of the highest funding issues due to diverse formats and technology requirements. Copyright is also an issue in music library special collections, and few case studies are available to show how music libraries elude troubles with it. As technology progresses, the economy continues to fluctuate, institutional financial support continues to be cut, and the technological needs of the

\footnotetext{
${ }^{72}$ Joan van Albada, ed., Financing Archival Services: Proceedings of the Twenty-Eighth International Conference of the Round Table on Archives (Haarlem: International Council on Archives, 199) $145-46$.
} 
library's patrons become more savvy, music libraries (and their librarians) will have to supplement funds somehow. 


\section{APPENDIX A:}

1) Name:

2) Education:

3) Institution:

4) Job title:

5) Number of years at this institution or in current position:

6) Does your institution have archival, rare or special manuscript collections? If yes, please briefly describe.

7) Tell me about your staff. Specifically, who is responsible for preservation/conservation, digital activities, and fundraising (if applicable)?

8) Has your institution decided to enter into any fundraising activity in the last year? If yes, what activity or activities did you pursue?

9) What was the purpose or need for pursuing fundraising? What was your end goal?

10) How would you rate the success of your recent fundraising activities?

11) What activities (if any) were attempted by your institution for fundraising efforts in the past?

12) What percentage or your preservation, conservation and digitization efforts, if any, were funded by fundraising opportunities?

13) Have you used your University's or Library's development officer to assist in the fundraising process? If so, were these efforts successful?

If you have any comments on fundraising, or specifically fundraising for preservation or digitization, please list them here: 


\section{APPENDIX B:}

1) Name: Alec McLane

2) Education: M.M., DMA, MLS

3) Institution: Wesleyan University

4) Job title: Music Librarian / Director of World Music Archives

5) Number of years at this institution or in current position: 9

6) Does your institution have archival, rare or special manuscript collections? If yes, please briefly describe.

The library has a Special Collections department for print materials, but I'm not involved with that, so I will describe our sound recording archives. It is a collection of around 6000 recordings on reel, cassette, DAT, and CD. These are mostly original unpublished field recordings made all over the world, or else recordings of concerts on campus. Most recordings have been duplicated as both master and listening copies.

7) Tell me about your staff. Specifically, who is responsible for preservation/conservation, digital activities, and fundraising (if applicable)?

I have two .75 FTE staff. Both have been involved in cataloging the Archives, but one in particular is completely devoted to preservation (analog and digital) and occasional fundraising. In addition, there are graduate student workers totaling ca. 1.5 FTE who do most of the preservation work.

8) Has your institution decided to enter into any fundraising activity in the last year? If yes, what activity or activities did you pursue?

Yes. We submitted a Grammy Foundation preservation grant proposal and an NEH preservation assessment grant proposal.

9) What was the purpose or need for pursuing fundraising? What was your end goal?

We have a donated collection of ca. 3000 tapes and haven't the resources to process this collection in our current situation. We were hoping to partner with other institutions and put parts of the collection online.

10) How would you rate the success of your recent fundraising activities?

No success at all yet (but still awaiting word on the NEH proposal).

11) What activities (if any) were attempted by your institution for fundraising efforts in the past? 
The Archives began with back-to-back NEH grants in the early 1990's to preserve and catalog the original collection of recordings.

12) What percentage or your preservation, conservation and digitization efforts, if any, were funded by fundraising opportunities?

In the beginning, all of it. Since 1995 none at all.

13) Have you used your University's or Library's development officer to assist in the fundraising process? If so, were these efforts successful?

For the recent proposals we used the University's Foundation and Corporate Relations office. It was successful only in that they helped us compile the grant proposal and get it out in time, although we have twice been turned down.

If you have any comments on fundraising, or specifically fundraising for preservation or digitization, please list them here: 


\section{APPENDIX C:}

1) Name: Peter Munstedt

2) Education: BA, MA, MLS, PhD

3) Institution: MIT

4) Job title: Music Librarian

5) Number of years at this institution or in current position: 15 years

6) Does your institution have archival, rare or special manuscript collections? If yes, please briefly describe.

MIT has a special collections for the entire school. The Music Library has its own small special collections.

7) Tell me about your staff. Specifically, who is responsible for preservation/conservation, digital activities, and fundraising (if applicable)?

The MIT Libraries employs people that work on all three of these areas.

8) Has your institution decided to enter into any fundraising activity in the last year? If yes, what activity or activities did you pursue?

MIT has a large development office. The Libraries employ 2.5 staff members who work in library development.

9) What was the purpose or need for pursuing fundraising? What was your end goal?

The goal of the Lewis Music Library fundraising efforts has been to obtain funding for special projects (such as the music library renovation, funding to staff the Music at MIT Oral History project) and to supplement the collections budget.

10) How would you rate the success of your recent fundraising activities?

The music library has been successful in obtaining money for projects and general library support. We have increased the size of our mailing list and our donor base significantly during the past ten years. The major gift we obtained was one to renovate our library 11 years ago.

11) What activities (if any) were attempted by your institution for fundraising efforts in the past?

MIT has completed a major capital campaign. The music library has attempted to raise money from individuals rather than seeking grant money. Working with private donors has resulted in a few large gifts as well as many small donations mostly from MIT alums. 
12) What percentage or your preservation, conservation and digitization efforts, if any, were funded by fundraising opportunities?

I do not have percentages, but the MIT Libraries obtained a large gift to renovate its preservation lab (see newsletter article in:

http://malgosia.mit.edu/about/news/newsletter/05-02.pdf. The music library obtained donations from alums to support the reformatting of 72 MIT Symphony Orchestra concerts from reel-to-reel tape to CD.

13) Have you used your University's or Library's development officer to assist in the fundraising process? If so, were these efforts successful?

Yes, I am in contact very often with the Library's development officer. We have been fairly successful. The latest success was the support of a half-time staff position in the music library to work on the Music at MIT Oral History project. Funding for this project will last at least 5 years.

14) If you have any comments on fundraising, or specifically fundraising for preservation or digitization, please list them here: 


\section{BIBLIOGRAPHY}

Albada, Joan van, ed. Financing Archival Services: Proceedings of the Twenty-Eighth International Conference of the Round Table on Archives. Haarlem: International Council on Archives, 1991.

Alexander, Johanna O. "Fundraising for the Evolving Academic Library: The Strategic Small Shop Advantage." The Journal of Academic Librarianship 24, no. 2 (1998): 131-38.

Balas, Janet L. "Looking for Funds in All the Right Places." Computers in Libraries 26, no. 8 (2006): 23-5.

Bonnell, Pamela G. Fund Raising for the Small Library. Small Libraries Publication Series, 8. Chicago: American Library Association, 1983.

Browar, Lisa, and Samuel A. Streit. "Mutually Assured Survival: Library Fund-raising Strategies in a Changing Economy." Library Trends 52, no. 1 (Summer 2003): 69-86.

Butler, Meredith, ed. Successful Fundraising: Case Studies of Academic Libraries. Washington, DC: Association of Research Libraries, 2001.

Claassen, Lynda C., comp. Library Development and Fundraising: A SPEC Kit. Edited by Brigid Welch. Washington, DC: Association of Research Libraries, 1993.

Clark, Charlene K. "Getting Started with Annual Funds in Libraries." Journal of Library Administration 12, no. 4. (1990): 73-87.

Corson-Finnerty, Adam. “Cybergifts.” Library Trends 48, no. 3 (Winter 2000): 619-33.

Corson-Finnerty, Adam, and Laura Blanchard. Fundraising and Friend-Raising on the Web. Chicago: American Library Association, 1998.

Crutsinger, Gene. "Introducing Fundraising to a Seminary Library." MA, Kent State University, 1999.

Dewey, Barbara I., ed. Raising Money for Academic and Research Libraries: A How-ToDo-It Manual for Librarians. New York: Neal-Schuman Publishers, 1991.

Gerding, Stephanie, and Pam Mackellar. "Wishing Won't Work: 10 Things you Need to KNOW and DO When Applying for Technology Grants." Computers in Libraries 26, no. 7 (July/August 2006): 6-16.

Grabowski, John J. “Keepers, Users, and Funders: Building an Awareness of Archival 
Value." In American Archival Studies: Readings in Theory and Practice, edited by Randall C. Jimerson, 619-29. Chicago: The Society of American Archivists, 2005.

Gwinn, Nancy E. "Funding for Preservation: The Strengths of Our Past" In To Preserve and Protect: The Strategic Stewardship of Cultural Resources, 141-48.

Washington, DC: Library of Congress, 2002.

. "Mapping the Intersection of Selection and Funding." Collection Management 22, no. 3/4 (1998): 143-49.

Hall-Ellis, Sylvia D., Doris Meyer, Frank W. Hoffmann, and Ann Jerabek. Grantsmanship for Small Libraries and School Library Media Centers. Edited by Frank W. Hommann. Englewood, CO: Libraries Unlimited, Inc., 1999.

Hazard, Brenda L. "Online Fundraising at ARL Libraries." Journal of Academic Librarianship 29, no.1 (January 2003): 8-15.

Hoffman, Irene M., Amy Smith and Leslie DiBona. "Factors for Success: Academic Library Development Survey Results.” Library Trends 48, no. 3 (Winter 2000): 540-50.

Hohmann, Judy P. "Money Talk.” In Advocating Archives: An Introduction to Public Relations for Archivists, edited by Elsie Freeman Finch, 23-38. Metuchen, NJ: The Society of American Archivists and the Scarecrow Press, 1994.

Hood, Joan M. "Financing Library Services: Changing Approaches - Finding New Sources of Financial Aid for Libraries." Conference Proceedings of the SixtySecond IFLA General Conference. (August 1996). http://www.ifla.org/IV/ifla62/62-hooj.htm (accessed November 20, 2007).

Jennings, Karlene Noel, and Jos Wanschers, eds. SPEC Kit 297: Library Development. Washington, DC: Association of Research Libraries, 2006.

Latour, Terry Stephen. "Study of Library Fund Raising Activities at Colleges and Universities in the United States.” PhD diss., Florida State University, 1995.

Lee, Hwa-Wei, and Gary A. Hunt. Fundraising for the 1990s The Challenge Ahead: A Practical Guide for Library Fundraising; From Novice to Expert. Canfield, OH: Genaway \& Associates, 1992.

Martin, Susan K. "Academic Library Fund-Raising: Organization, Process and Politics." Library Trends 48, no. 3 (Winter 2000): 560-78.

. "The Changing Role of the Library Director: Fund-raising and the Academic Library." Journal of Academic Librarianship 24, no. 1 (January 1998): 3-10. 
McCune, Bonnie. "10 Tips for Getting Grants to Keep Your Library Afloat." Computers in Libraries 27, no. 7 (July/August 2007):10-12.

Morrow, Carolyn Clark. "Defining the Library Preservation Program: Policies and Organization." In Preservation: Issues and Planning, ed. Paul N. Banks and Roberta Pilette, 1-27. Chicago: American Library Association, 2000.

Neal, James G. "Strategies for Funding Preservation and Security." In To Preserve and Protect: The Strategic Stewardship of Cultural Resources, 155-60. Washington, DC: Library of Congress, 2002.

Pace, Andrew K. "Money Makes the Library Go 'Round." Computers in Libraries 23, no. 2 (February 2003): 29.

Paustenbaugh, Jennifer. "Fundraising for Special Collections." The Bottom Line: Managing Library Finances 15, no. 4 (December 2002).

Paustenbaugh, Jennifer, and Lynn Trojahn. "Annual Fund Programs for Academic Libraries." Library Trends 48, no. 3 (Winter 2000): 579-96.

Reed, Sally G. Making the Case for Your Library: A How-To-Do-It Manual. New York: Neal-Schuman, 2001.

Shoaf, Eric C. "Brown University Library Meets the Preservation Challenge: A Challenge Grant Leads to a Preservation Endowment." College \& Research Libraries News 61, no. 7 (August 2000): 593-95.

Steele, Victoria, and Stephen D. Elder. Becoming a Fundraiser: The Principles and Practice of Library Development. Chicago: American Library Association, 1992.

Swan, James. Fundraising for Libraries: 25 Proven Ways to Get More Money for Your Library. New York: Neal-Schuman Publishers, 2002.

Ward, Christine. "Preservation Program Planning for Archives and Historical Records Repositories." In Preservation: Issues and Planning, ed. Paul N. Banks and Roberta Pilette, 43-62. Chicago: American Library Association, 2000.

Wedgeworth, Robert. "Donor Relations as Public Relations: Toward a Philosophy of Fund-Raising." Library Trends 48, no. 3 (Winter 2000): 530-39.

Welch, Jeanie M. "The Electronic Welcome Mat: The Academic Library Web Site as a Marketing and Public Relations Tool." The Journal of Academic Librarianship 31, no. 3 (May 2005): 225-28.

Winning the Money Game: A Guide to Community-Based Library Fundraising. New York: The Baker \& Taylor Company, 1979. 
Winston, Mark D. and Lisa Dunkley. "Leadership Competencies for Academic Librarians: The Importance of Development and Fund-Raising." College \& Research Libraries News 63, no. 2 (March 2002): 171-82. 